\title{
Studies on the energy metabolism of the pregnant sow
}

\section{The partition and utilization of metabolizable energy intake in pregnant and non-pregnant animals}

\author{
BY W. H. CLOSE*, J. NOBLET $\dagger$ AND R. P. HEAVENS \\ AFRC Institute of Animal Physiology, Babraham, Cambridge CB2 4AT
}

(Received 1 February 1984 - Accepted 7 September 1984)

1. The heat losses and energy and nitrogen balances of pregnant gilts, and of their non-pregnant litter sisters (controls), were measured for periods of $7 \mathrm{~d}$ at feed intakes of 1.8 or $2.5 \mathrm{~kg} / \mathrm{d}$ ( 20 or $30 \mathrm{MJ}$ metabolizable energy (ME) respectively) at an environmental temperature of $20^{\circ}$. The measurements were made within three separate periods of gestation; 40-60 d (early), 60-80 d (mid) and 90-110 d (late). Values for ME intake, heat loss, energy retention (ER), protein deposition and fat deposition were determined for both the pregnant and control animals on each treatment.

2. When expressed per $\mathrm{kg}$ body-weight ${ }^{0.75}$ per $\mathrm{d}$, there was little difference in heat loss between pregnant and non-pregnant animals and between pregnant animals at the different stages of gestation at any given ME intake. However, heat loss was higher at the higher ME intake.

3. ER varied inversely with heat loss. The decrease in ME intake $\left(\mathrm{kJ} / \mathrm{kg}\right.$ body-weight $\mathrm{t}^{9 \cdot 75}$ per d) during pregnancy resulted in a decrease in ER so that the pregnant animals were in negative energy balance at the low feed intake during late gestation. From the relation between ER and ME intake, estimates of the maintenance energy requirement $\left(\mathrm{ME}_{\mathrm{m}}\right)$ of 411 and $401 \mathrm{~kJ} / \mathrm{kg}$ body-weight $\mathrm{t}^{0-75}$ per $\mathrm{d}$ were calculated, with corresponding partial efficiencies of energy utilization $(k)$ of 0.74 and 0.68 for the pregnant and non-pregnant animals respectively.

4. For the pregnant animals, protein deposition was highest during mid-pregnancy and was relatively independent of level of feeding during mid- and late pregnancy. There was little difference in protein deposition between pregnant and non-pregnant animals at the high feed intake. At the low feed intake, the pregnant animals generally had a higher protein deposition than their non-pregnant litter sisters and this was entirely associated with the accretion in reproductive tissue.

5. Fat deposition depended on the level of feeding, and at any given ME intake was similar for pregnant and control animals. In late gestation the low level of feeding was insufficient to prevent the pregnant animals losing fat. It was calculated that at term these animals lost $140 \mathrm{~g}$ fat/d from maternal stores.

6. From the relation between $M E$ intake and protein and fat deposition, estimates of $M_{m}$ and the energetic efficiencies of protein $\left(k_{p}\right)$ and fat $\left(k_{f}\right)$ deposition were determined. There was little difference in $\mathrm{ME}_{\mathrm{m}}(422$ and $420 \mathrm{~kJ} / \mathrm{kg}$ body-weight ${ }^{0} \cdot{ }^{\cdot 75}$ per d) and $k_{f}(0.88$ and 0.90$)$ between pregnant and non-pregnant animals respectively. However, the pregnant animals had a higher $k_{p}(0.69$ compared with 0.49 for controls $)$ and this reflected the higher rates of protein deposition associated with pregnancy.

7. The efficiency of energy deposition in the reproductive tissue was calculated to be 0.72 .

Pregnancy appears to stimulate weight gain in animals in excess of that accounted for by uterine and mammary tissue development (Salmon-Legagneur \& Rerat, 1962; Lodge, 1972). The additional gain may be attributed to changes in the rate and composition of net maternal tissue deposition and, in both humans and farm animals, part of this additional weight gain is associated with hydration of the maternal tissues (Leitch, 1957; Robertson, 1969; Robinson et al. 1978). Using the technique of carcass analysis, Heap \& Lodge (1967) observed that pregnant sows had more carcass muscle and less carcass fat than non-pregnant animals at similar feed intakes, in agreement with the findings of Salmon-Legagneur (1965). Elsley et al. (1966) found less subcutaneous fat but more muscle in the carcasses of pregnant gilts compared with non-pregnant gilts, even though the additional weight gain associated with pregnancy was attributed to the reproductive tract, mammary tissue and blood. On

\footnotetext{
* Present address: National Institute for Research in Dairying, Shinfield, Reading RG2 9AT.

$\dagger$ Present address: INRA, Station de Recherches sur l'Elevage des Porcs, Centre de Rennes - Saint Gilles, 35590 , l'Hermitage, France.
} 
the other hand, Hovell et al. (1977a) reported no evidence of any pregnancy anabolism other than that involving the conceptus, that is the need of the dam for pregnancy and preparation for lactation. This finding has been confirmed by the investigations of De Wilde $(1980 a, b)$ and Shields \& Mahan (1983).

If there are differences between pregnant and non-pregnant animals of similar age and body size, these might be accounted for by an increased efficiency of energy and protein utilization in the pregnant animals. Brody (1938), Verstegen et al. (1971) and De Lange et al. (1980), on the other hand, have shown that heat production increased markedly during pregnancy, suggesting a decrease in the efficiency of energy utilization or an increase in the animal's maintenance energy requirement. There is little available information to show the extent to which tissue deposition and the efficiency of energy utilization change during pregnancy. The present experiments were designed to provide such information by examining the partition of metabolizable energy (ME) intake in pregnant and non-pregnant gilts at two levels of feed intake.

\section{MATERIALS AND METHODS}

Details of the animals, their selection, nutrition and management have been reported by Noblet et al. (1985).

Calorimetry. Following the 4-week period of habituation within the temperature-controlled farrowing house, the animals were removed to a specially designed calorimeter maintained at 20 (SE 0.5$)^{\circ}$. The calorimeter, which was of the direct, heat-sink type, was constructed within a temperature-controlled room which acted as a shell-space around the calorimeter. The construction was mainly of wood, insulated with $50 \mathrm{~mm}$ expanded polystyrene. The animal was contained within a farrowing crate mounted on an insulated concrete base within the calorimeter (Close et al. 1978).

Sensible and evaporative heat losses were recorded continuously throughout the $7 \mathrm{~d}$ experimental period and calculated as the mean hourly rate for each $24 \mathrm{~h}$ period. Sensible heat loss was recorded from an automatically-operated heat exchanger constructed on top of the calorimeter and through which water was continuously circulating. Evaporative heat loss was measured from the wet-and-dry bulb temperatures of the inlet and exhaust air.

Collection of excreta. Facilities were provided within the calorimeter for the collection of excreta voided by the animal during the $7 \mathrm{~d}$ balance period. The urine voided by the animal flowed through a welded mesh floor on to a tapered stainless-steel sink base beneath the floor and was collected in a receptacle, containing $50 \mathrm{ml} 0.5 \mathrm{M}$-sulphuric acid, outside the calorimeter. The voided urine was collected twice daily and was kept in a cold room at $2^{\circ}$ until the end of each experiment. The faeces voided by the animal were either collected on the welded mesh floor or dropped on to the stainless-steel base. These were removed on three occasions within the $7 \mathrm{~d}$ experimental period. The calorimeter was cleaned three times each week when the animal was removed from the calorimeter and held in a large mobile trolley. The procedure for cleaning the calorimeter was to remove all solid material and then to wash the floor area and the stainless-steel base with water. Both faeces and washings were also stored at $2^{\circ}$. The cleaning and collection process was completed within $15 \mathrm{~min}$ and before re-entry into the calorimeter the animal was weighed and its rectal temperature measured.

Sampling, chemical analysis and balance procedures. At the end of each $7 \mathrm{~d}$ calorimetric period, all samples of excreta were bulked, weighed and sampled for determination of their dry matter (DM), energy and nitrogen contents. In addition, samples of diet were also analysed. The urine and washings were analysed as a composite sample of mixed urine and 
washings. The DM contents of the feed and faeces were determined following drying to constant weight in a forced-air oven maintained at $70^{\circ}$. The DM content of the mixed urine and washings was determined following freeze-drying. The heats of combustion of the diet and excreta were determined in an adiabatic bomb calorimeter. The $\mathrm{N}$ contents were measured in the fresh material according to the Kjeldahl method.

The ME of the diet was calculated as the difference between the gross energy (GE) of the feed and that of the faeces, mixed urine and washings and methane, the latter being assumed to be $1 \%$ of the GE of the feed. The $\mathrm{N}$ retained by the animals was calculated from the difference between the $\mathrm{N}$ in the feed and that of the faeces, mixed urine and washings and the ammonia generated within the calorimeter. The latter was measured by the method described by Verstegen et al. (1973). The energy retained (ER) by the animals was calculated as the difference between ME intake and heat loss, whereas fat deposition was calculated as the difference between ER and protein deposition. Protein deposition was calculated from the $\mathrm{N}$ balance on the basis that protein contained $160 \mathrm{~g} \mathrm{~N} / \mathrm{kg}(\mathrm{N} \times 6.25)$ and had an energy value of $23.8 \mathrm{~kJ} / \mathrm{g}$ (Brouwer, 1965).

Since the chemical composition of the reproductive tissue was known, it was possible to partition total ER and protein and fat deposition into their net maternal and reproductive components. The changes in the reproductive tissues, that is the gravid uterus and mammary tissue, have been made for each pregnant animal from the equations presented by Noblet et al. (1985).

\section{Statistical analysis}

Because of the treatments imposed upon the animals and the variation in initial body-weight, there were differences in body-weight between pregnant and non-pregnant animals at the different stages of gestation, as occurs in practice. This influenced the use that the animals made of their feed. In an attempt to overcome the variation associated with these differences, the results have been expressed per unit of metabolic body-size. The exponent of body-weight in the relation between the logarithm of heat loss $(\mathrm{MJ} / \mathrm{d} ; y)$ and the logarithm of body-weight $(\mathrm{kg} ; x)$ in the present experiments was calculated to be 0.73 and, since this is not significantly different $(P>0.05)$ from the more commonly-applied value of 0.75 (Kleiber, 1961), the latter has been used in evaluating the results.

\section{RESULTS}

For each group of pregnant animals, at each stage of gestation and at each feeding level, it was intended that there would be a comparable group of non-pregnant litter sisters. However, for the animals in late pregnancy, it was not possible to arrange groups of non-pregnant litter sisters. At the low feeding level a series of control animals of similar body-weight and age was arranged. At the high feeding level, the comparable control animals were younger and of lower body-weight than the pregnant animals.

There were no differences between groups in rectal temperature; the mean value was $39 \cdot 1$ $(\operatorname{SE} 0 \cdot 1)^{\circ}$.

\section{Feed intake}

No problems were experienced with the animals within the calorimeter and they generally spent most of the time lying. There were no differences between pregnant and control animals in the metabolizability (ME/GE) of the dietary energy. Although there was a tendency for metabolizability to decrease with increase in body-weight, the effect was not significant $(P>0.05)$. The mean metabolizability of the feed was 0.74 (SE 0.004$)$. 
Table 1. The partition of metabolizable energy $(M E)$ intake $\left(k J / k g\right.$ body-weight ${ }^{0.75}$ per $\left.d\right)$ into heat loss, energy retention $(E R)$, protein and fat deposition in gilts at several stages of gestation and of non-pregnant (control) animals of similar age

(Mean values with their standard errors)

\begin{tabular}{|c|c|c|c|c|c|c|c|c|c|c|c|c|c|}
\hline \multicolumn{2}{|c|}{$\begin{array}{c}\text { Body-wt } \\
\text { during } \\
\text { balance } \\
\text { period } \\
(\mathrm{kg})\end{array}$} & \multicolumn{2}{|c|}{$\begin{array}{l}\text { Stage of } \\
\text { gestation } \\
\text { (d) }\end{array}$} & \multicolumn{2}{|c|}{ ME } & \multicolumn{2}{|c|}{$\begin{array}{l}\text { Heat } \\
\text { loss }\end{array}$} & \multicolumn{2}{|c|}{ ER } & \multicolumn{2}{|c|}{ Protein } & \multicolumn{2}{|c|}{ Fat } \\
\hline Mean & SE & Mean & $\mathrm{SE}$ & Mean & SE & Mean & SE & Mean & $\mathbf{S E}$ & Mean & SE & Mean & $\mathbf{S E}$ \\
\hline \multicolumn{14}{|c|}{ Pregnant animals } \\
\hline 120 & 5 & 47 & 2 & 565 & 26 & 440 & 5 & 125 & 28 & 22 & 10 & 103 & 33 \\
\hline 139 & 4 & 49 & 2 & 722 & 14 & 427 & 7 & 295 & 14 & 27 & 4 & 268 & 14 \\
\hline 146 & 1 & 75 & 1 & 490 & 6 & 403 & 4 & 87 & 2 & 39 & 2 & 48 & 2 \\
\hline 147 & 4 & 68 & 2 & 668 & 14 & 492 & 9 & 176 & 8 & 41 & 2 & 135 & 9 \\
\hline 155 & 1 & 97 & 3 & 441 & 5 & 452 & 15 & -11 & 18 & 34 & 3 & -45 & 16 \\
\hline 200 & 6 & 98 & 3 & 552 & 10 & 444 & 9 & 108 & 9 & 35 & 3 & 73 & 11 \\
\hline \multicolumn{14}{|c|}{ Non-pregnant animals } \\
\hline 115 & 5 & 51 & 4 & 576 & 30 & 436 & 13 & 140 & 33 & 28 & 5 & 112 & 34 \\
\hline 140 & 6 & 47 & 8 & 741 & 31 & 430 & 15 & 311 & 17 & 11 & 4 & 300 & 14 \\
\hline 129 & 2 & 80 & 6 & 541 & 16 & 436 & 10 & 105 & 7 & 23 & 6 & 82 & 3 \\
\hline 132 & 5 & 69 & 4 & 719 & 19 & 505 & 12 & 214 & 43 & 42 & 4 & 172 & 21 \\
\hline 136 & 3 & 108 & 6 & 516 & 15 & 443 & 12 & 73 & 16 & 26 & 5 & 47 & 21 \\
\hline 154 & 10 & 97 & 2 & 652 & 23 & 503 & 6 & 149 & 27 & 33 & 11 & 116 & 17 \\
\hline
\end{tabular}

\section{The partition of $M E$ intake}

Heat loss. The heat loss of the pregnant and non-pregnant animals increased with both level of feed intake and stage of gestation. Between early and late gestation, heat loss was 1.57 and $1.43 \mathrm{MJ} / \mathrm{d}$ higher in the pregnant animals than in the control animals at the low and high feeding levels respectively. Since the variation in the body-weight of the animals could have contributed to this difference, the results have been expressed per $\mathrm{kg}$ body-weight $\mathrm{t}^{\cdot 75}$ to normalize the variation associated with these differences (Table 1).

Within each of the experimental treatments there was little variation in heat loss between animals when the results were expressed per $\mathrm{kg}$ body-weight ${ }^{0 \cdot 75}$. Increasing the level of energy intake was generally associated with an increase in heat loss for all animals. The exceptions were the pregnant and control animals given the high feed intake during early gestation, and the pregnant animals given the low intake during late pregnancy. The increased heat loss of the latter may be associated with changes in their physiological state since they were in negative energy balance (see p. 275). There is no apparent reason for the reduction in heat loss of the animals at the high feed intake in early gestation, but both pregnant and control animals were similarly affected. In addition, the protein retention of the control animals on this treatment was less than that of corresponding animals on the low feed intake. With the exception of these groups of animals, and when differences in body-weight and hence in ME intake were taken into account, there was little difference in heat loss between pregnant and non-pregnant animals or between the different stages of gestation. Evaporation was also independent of the treatments and, as a percentage of total heat loss, averaged 21 (SE 0.9) for all treatments.

Energy retention. ER increased with an increase in food intake in both control and pregnant animals at each stage of gestation (Table 1). As a result of the increase in 


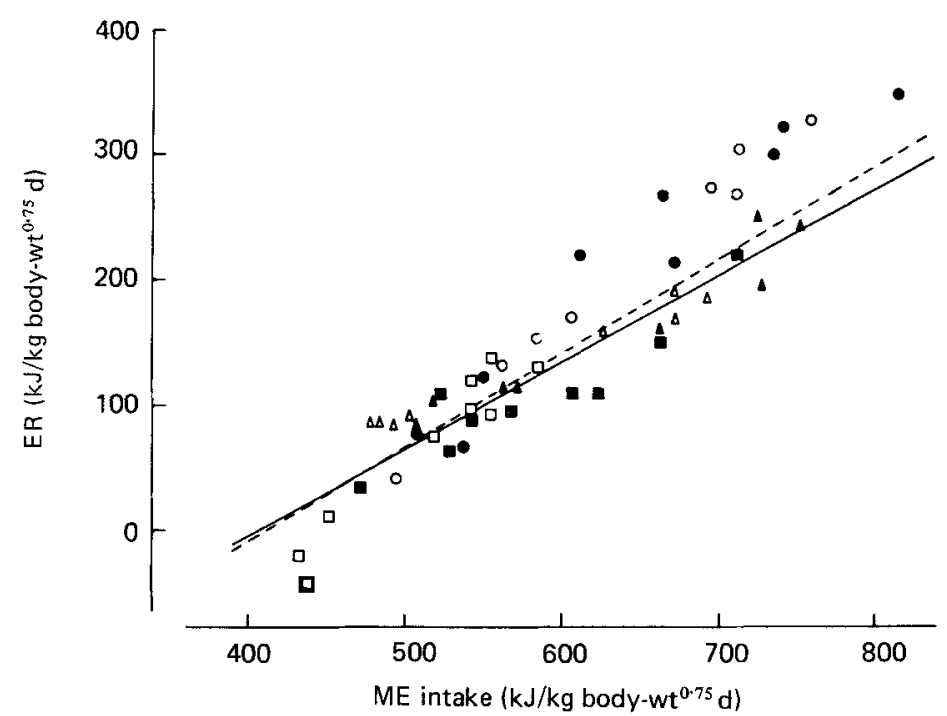

Fig. 1. Energy retention (ER; $\mathrm{kJ} / \mathrm{kg}$ body-weight ${ }^{0.75}$ per $\mathrm{d}$ ) in relation to metabolizable energy (ME) intake $\left(\mathrm{kJ} / \mathrm{kg}\right.$ body-weight $\mathrm{t}^{\cdot 75}$ per d) for pregnant animals at several stages of gestation compared with their non-pregnant litter sisters. Gestational stage: $(O)$, early; $(\triangle)$, middle; $(\square)$, late. $(O, \triangle, \square)$, Pregnant animals; $(\boldsymbol{O}, \boldsymbol{\Delta}, \boldsymbol{\square})$, non-pregnant animals. (-..-), Regression line for pregnant animals calculated from eqn (3). (-), Regression line for control animals calculated from eqn (4).

body-weight, and hence the decrease in ME/ $\mathrm{kg}$ body-weight ${ }^{0.75}$ per d, ER decreased with stage of gestation. The extent of the decrease was such that the animals on the low feed intake were in negative energy balance during late gestation. From the linear regression equations relating ER $\left(y ; \mathrm{kJ} / \mathrm{kg}\right.$ body-weight $t^{0.75}$ per d) to ME intake $(x ; \mathrm{kJ} / \mathrm{kg}$ bodyweight $^{\cdot \cdot 75}$ per d), it was possible to obtain estimates of the animals' maintenance energy requirements $\left(\mathrm{ME}_{\mathrm{m}}\right)$ and their partial efficiencies of energy utilization $(k)$ (Fig. 1). The equations were:

$$
\begin{aligned}
& \text { pregnant animals: } y=0.77 \text { (SE 0.10) } x-301 \text { (SE 54) }(r 0.95 \text { ), }
\end{aligned}
$$

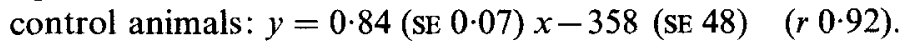

Estimates of $\mathrm{ME}_{\mathrm{m}}$, calculated as the intake equivalent to zero ER, were 391 and $426 \mathrm{~kJ} / \mathrm{kg}$ body-weight $t^{0.75}$ per $\mathrm{d}$, for pregnant and non-pregnant animals respectively. The corresponding values of $k$ were 0.77 and 0.84 . The data used in compiling eqns (1) and (2) included values for both the pregnant and control animals given the high intake in early gestation when heat loss appeared particularly low considering the energy intake. When these groups of values were excluded from the analysis the equations became:

$$
\begin{aligned}
\text { pregnant animals: } y=0.74 \text { (SE 0.07) } x-304 \text { (SE 41) } & (r 0.91), \\
\text { control animals: } y=0.68 \text { (SE 0.07) } x-273 \text { (SE 45) } & (r 0.90) \text {. }
\end{aligned}
$$

From these equations estimates of $\mathrm{ME}_{\mathrm{m}}$ of 411 and $401 \mathrm{~kJ} / \mathrm{kg}$ body-weight ${ }^{\cdot \cdot 75}$ per d, with corresponding $k$ values of 0.74 and 0.68 , were calculated for pregnant and non-pregnant gilts respectively. This suggests that there is little difference between pregnant and non-pregnant animals in their energy requirements for maintenance or the efficiency with which energy is used for productive purposes. The latter are typical of values determined within the zone of thermal neutrality.

The partition of total $E R$ into its net maternal $\left(E_{M}\right)$ and reproductive components $\left(E_{R}\right)$ showed that although $\mathrm{ER}_{\mathrm{R}}$ increased with stage of gestation, it was only in late gestation 


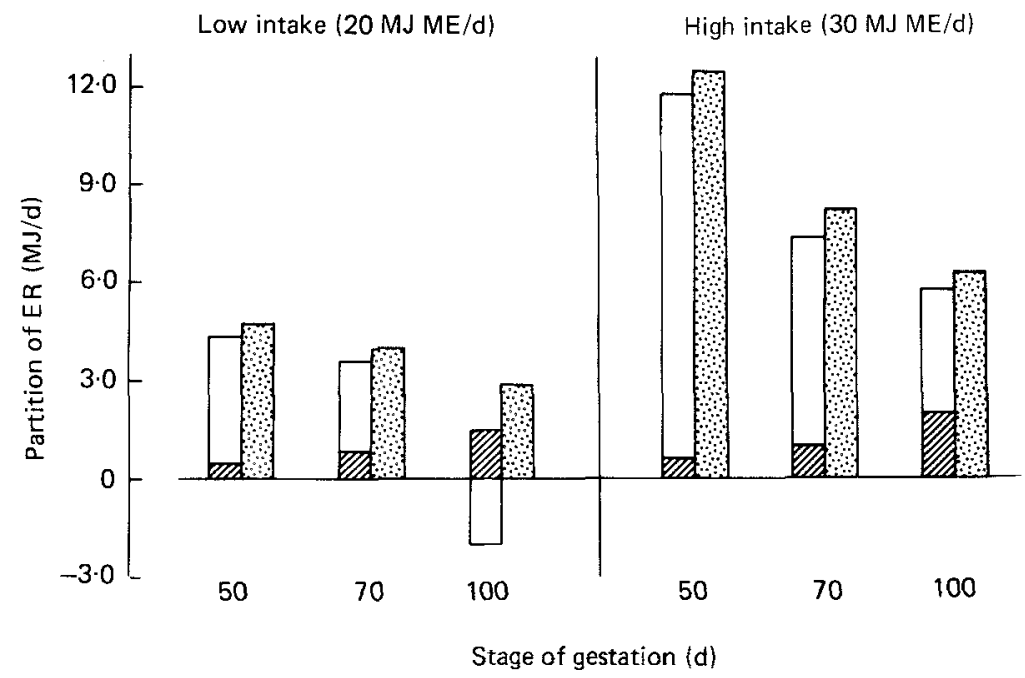

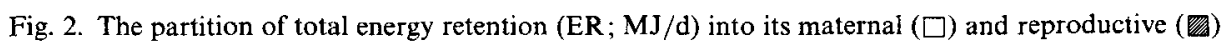
components at different stages of gestation and at two levels of metabolizable energy (ME) intake. The values of ER for the non-pregnant litter sisters are provided for comparison (圆).

Table 2. The nitrogen intake $(N I)$ and $N$ retention $(N R)\left(g / k g\right.$ body-weight ${ }^{0.75}$ per $\left.d\right)$, apparent digestability of $N(A D N, \%)$ and $N R / N I$ of pregnant gilts in relation to level of intake and stage of gestation, and of non-pregnant (control) animals of similar age

(Mean values with their standard errors)

\begin{tabular}{|c|c|c|c|c|c|c|c|c|c|}
\hline \multicolumn{2}{|c|}{$\begin{array}{l}\text { Stage of } \\
\text { gestation } \\
\text { (d) }\end{array}$} & \multicolumn{2}{|c|}{ NI } & \multicolumn{2}{|c|}{ NR } & \multicolumn{2}{|c|}{$\mathrm{ADN}$} & \multicolumn{2}{|c|}{$\mathrm{NR} / \mathrm{NI}$} \\
\hline Mean & $\mathrm{SE}$ & Mean & SE & Mean & SE & Mean & SE & Mean & SE \\
\hline \multicolumn{10}{|c|}{ Pregnant animals } \\
\hline 47 & 2 & $1 \cdot 10$ & 0.05 & 0.15 & 0.07 & $74 \cdot 5$ & 1.2 & $0 \cdot 183$ & 0.08 \\
\hline 49 & 2 & 1.39 & 0.03 & $0 \cdot 18$ & 0.03 & $79 \cdot 7$ & 1.9 & $0 \cdot 162$ & 0.02 \\
\hline 75 & 1 & $0-95$ & 0.01 & $0-26$ & 0.01 & $75 \cdot 6$ & $2 \cdot 6$ & 0.362 & 0.02 \\
\hline 68 & 2 & $1 \cdot 39$ & 0.03 & 0.28 & $0 \cdot 01$ & $71 \cdot 7$ & 0.6 & $0 \cdot 280$ & 0.02 \\
\hline 97 & 3 & 0.97 & 0.03 & $0 \cdot 23$ & 0.02 & $71 \cdot 7$ & $2 \cdot 4$ & 0.331 & 0.02 \\
\hline 98 & 3 & $1 \cdot 10$ & 0.03 & $0 \cdot 23$ & 0.02 & $75 \cdot 8$ & $3 \cdot 4$ & 0.276 & 0.02 \\
\hline \multicolumn{10}{|c|}{ Non-pregnant animals } \\
\hline 51 & 4 & $1 \cdot 14$ & 0.05 & 0.19 & 0.03 & $74 \cdot 1$ & $2 \cdot 2$ & 0.225 & 0.04 \\
\hline 47 & 8 & 1.38 & 0.05 & 0.07 & 0.03 & $79 \cdot 8$ & $1 \cdot 1$ & 0.064 & 0.02 \\
\hline 80 & 6 & $1 \cdot 06$ & 0.02 & $0 \cdot 16$ & $0 \cdot 04$ & $73 \cdot 7$ & $3 \cdot 5$ & 0.200 & 0.04 \\
\hline 69 & 4 & 1.48 & 0.06 & 0.28 & 0.02 & $72 \cdot 5$ & $3 \cdot 1$ & 0.262 & 0.02 \\
\hline 108 & 6 & 1.04 & 0.03 & $0 \cdot 18$ & 0.03 & $73 \cdot 2$ & $3 \cdot 1$ & $0 \cdot 243$ & 0.06 \\
\hline 97 & 2 & $1 \cdot 32$ & $0 \cdot 12$ & 0.23 & $0 \cdot 08$ & $72 \cdot 8$ & $3 \cdot 9$ & 0.229 & 0.07 \\
\hline
\end{tabular}

that it made a significant contribution to the total energy status of the animal (Fig. 2). Thus $E R_{R}$ at the high feeding level represented 0.34 of daily ER in late gestation. By contrast, $E R_{M}$ decreased during pregnancy and at the low feeding level the rate of decrease was such that at day 98 some $2.0 \mathrm{MJ} / \mathrm{d}$ were mobilized from maternal body reserves. This compares with an accretion rate of $3.0 \mathrm{MJ} / \mathrm{d}$ for the non-pregnant control animals. With the exception 


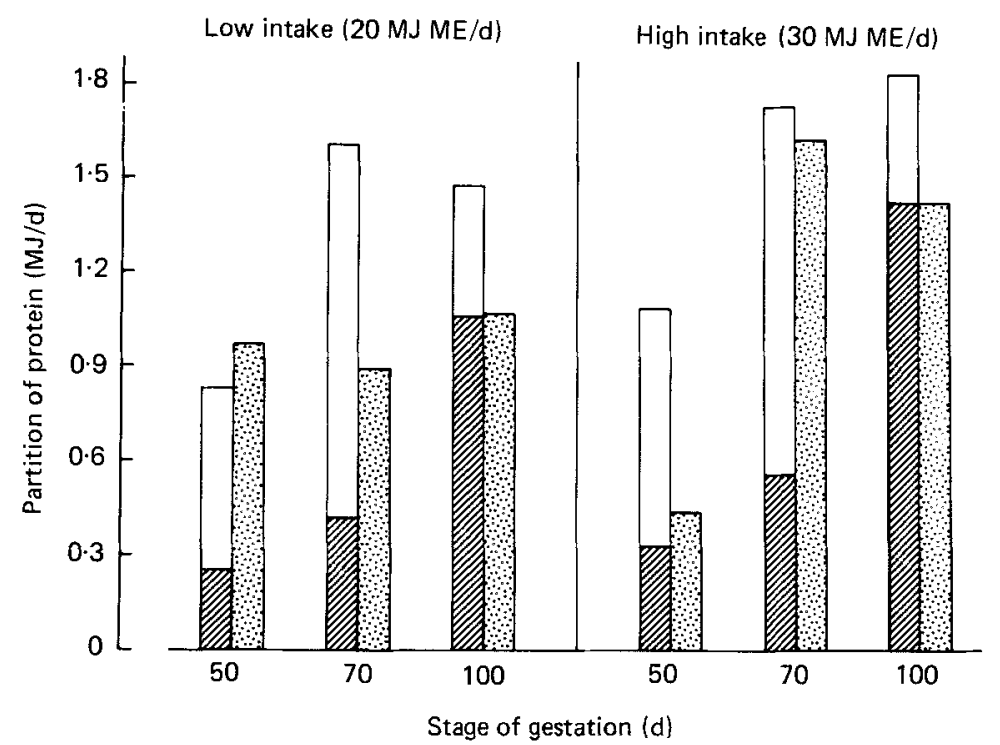

Fig. 3. The partition of total protein (MJ/d) into its maternal ( $\square$ ) and reproductive (哌) components at different stages of gestation and at two levels of metabolizable energy (ME) intake. The values of protein of the non-pregnant litter sisters are provided for comparison (圈).

of the values in early pregnancy the maternal deposition in the non-pregnant animals was always greater than that of their pregnant litter sisters.

Protein deposition. The mean values for protein deposition for each combination of feeding level and stage of gestation are given for both pregnant and non-pregnant animals in Table 1. In addition, values for the apparent digestibility of $\mathrm{N}$ and the efficiency of $\mathrm{N}$ utilization, that is the ratio, $\mathrm{N}$ retention :intake of apparently-digested $\mathrm{N}$, are given in Table 2. In contrast to the other measurements, there was great variability in the recorded values for $\mathrm{N}$ retention, not only between groups but also for animals within the same experimental treatment. This resulted in the coefficient of variation ranging between 4 and $44 \%$. Despite these variations there were quite distinct trends in the patterns and efficiencies of $\mathrm{N}$ metabolism. In general, an increase in $\mathrm{N}$ intake resulted in a higher $\mathrm{N}$ retention for both pregnant and non-pregnant animals at each period investigated. However, an exception to this was found in the control animals during the period corresponding to early gestation when the reduced $\mathrm{N}$ retention at the higher intake was accompanied by a $10-20 \%$ higher urinary $\mathbf{N}$ loss than the animals on the low intake. The apparent digestibility of $\mathrm{N}$ did not appear to be clearly related to the treatments imposed and varied within the range $0.72-0.79$ with the highest values being recorded in those animals given the high feed intake in early gestation.

The comparison of protein deposition for both pregnant and non-pregnant animals in Fig. 3 illustrates the pregnant animals' greater total protein deposition. However, this superiority resulted entirely from the reproductive component which increased throughout pregnancy. In late gestation the maternal protein deposition of the pregnant animals was similar at $0.42 \mathrm{MJ} / \mathrm{d}(18 \mathrm{~g}$ protein $/ \mathrm{d})$; this represented 28 and $23 \%$ of the total daily protein deposition on the low and high feeding levels respectively. The corresponding rates of protein deposition of the non-pregnant control animals were 1.04 and $1.44 \mathrm{MJ} / \mathrm{d}$, that is 


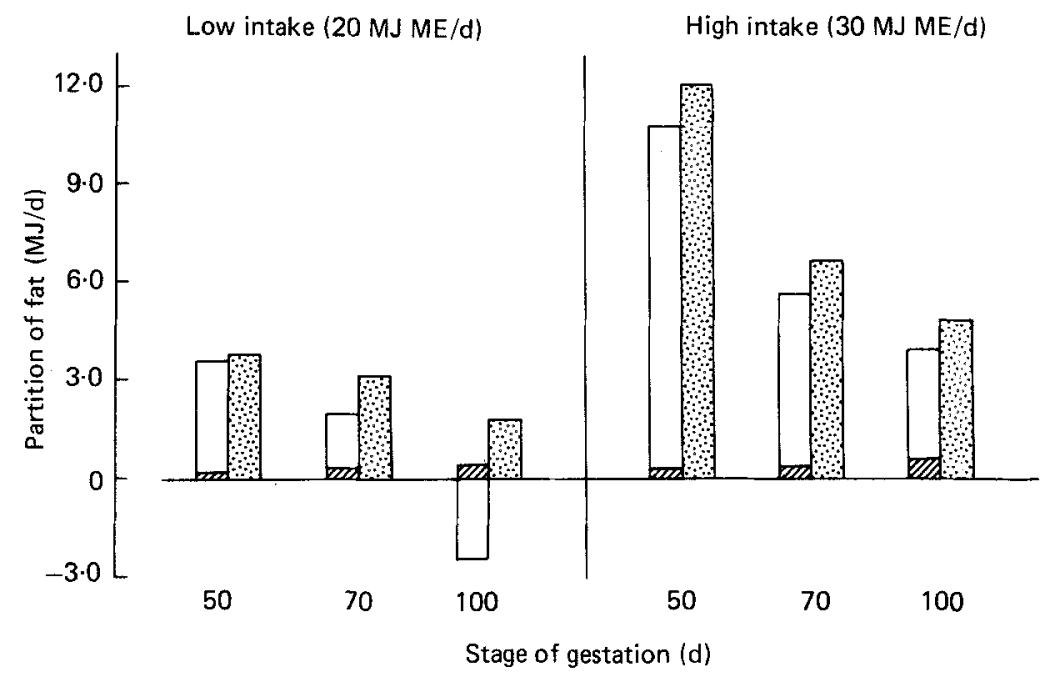

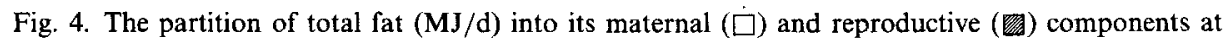
different stages of gestation and at two levels of metabolizable energy (ME) intake. The values of fat of the non-pregnant litter sisters are provided for comparison (鮝).

44 and $60 \mathrm{~g}$ protein/d. There is, therefore, no evidence that pregnancy enhanced the rate of protein deposition in the maternal tissues.

Fat deposition. A decrease in ME intake at each stage of gestation resulted in a decrease in total fat deposition. Fat deposition also decreased during pregnancy because of the reduction in ME per unit metabolic body-weight. This also accounts for the lower rates of fat deposition of the pregnant animals compared with their non-pregnant sisters at each stage of gestation. In late pregnancy the low feed intake was insufficient to prevent mobilization of body fat and, at day 98 , maternal fat reserves were being reduced by $61 \mathrm{~g} / \mathrm{d}$ (Fig. 4). As the animals were in negative fat balance from day 87 onwards, and assuming a linear increase with time in the rate of mobilization, it was calculated that the rate of fat catabolism from the maternal body at term would be $140 \mathrm{~g} / \mathrm{d}$. On the low feeding regimen used, and at an environmental temperature of $20^{\circ}$, some $1.6 \mathrm{~kg}$ of fat would therefore be lost from maternal body stores during pregnancy. This is in contrast to the pregnant animals given the high feed intake and the non-pregnant control animals which were in positive energy and fat balance at all times investigated.

With the exception of the animals in negative energy balance, a larger proportion of the $M E$ was deposited as fat than as protein. From the regression equations relating fat deposition to ME intake, the efficiency of conversion of ME into fat was calculated as 0.74 and 0.60 for the pregnant and control animals respectively, indicating that in mature animals it is primarily the rate and efficiency of fat deposition which determine the net efficiency of ER.

\section{Water intake}

There was little difference $(P>0.05)$ in water intake between the pregnant and control animals in relation to both stage of gestation and level of feeding. Mean intakes (with SE) were $0.033(0.002)$ and $0.036(0.002)$ litres $/ \mathrm{kg}$ body-weight per $\mathrm{d}$ for the pregnant and non-pregnant gilts respectively; per $\mathrm{kg}$ feed intake these represented 2.20 and 2.35 litres/d respectively. 


\section{DISCUSSION}

\section{The partition of $M E$ intake}

The results of the present investigations indicated that there was little difference in heat loss or ER between pregnant and non-pregnant animals when compared at similar body-weights and ME intakes. Since pregnancy results in an increase in body-weight, similar rates of ER can only be achieved by increasing the feed allocation of the pregnant animals. At similar levels of feed intake and at comparable ages the heat losses of the pregnant animals were greater than those of the non-pregnant litter sisters, particularly in middle and late gestation. This additional heat loss represents the heat increment associated with pregnancy and is directly related to the increased body-weight of the pregnant animals.

There were marked changes in ER at any given level of feed intake as pregnancy progressed. Animals in late pregnancy on the low feed intake were in negative energy balance and mobilized fat reserves. The energy deficit was greater than expected, suggesting that the heat loss in late gestation at this feed intake was higher than that in early gestation or at the higher level of feeding (Figs. 1 and 2). It is unlikely that the increased heat loss resulted from the animals being kept below their critical temperature since Holmes \& McLean (1974) have calculated the critical temperature of the sow at maintenance to be $18^{\circ}$.

There are a number of possibilities which could explain this increased metabolism in late gestation. (1) Following the long period of low level feeding, the body-weight of the animal is lower and the carcass is leaner than that of a younger animal or of an animal receiving a higher feed intake. The energy costs of maintaining this tissue may be higher. (2) In late gestation the animals on the low feed intake are in negative energy balance and maternal lipid is being mobilized to meet the energetic demands of the developing uterus and mammary tissue. This transfer of energy necessitates a cost to the animal which would increase its metabolism. (3) Relative to the sow's body-weight, the total weight of the uterus and mammary tissue is greater than it is in heavier animals or in animals receiving higher feed intakes. If the uterine and mammary tissues have higher metabolic rates than maternal tissues, then the heat production associated with pregnancy would be higher. A similar conclusion may be drawn from the findings of Verstegen et al. (1971).

Whereas the protein deposition of both the pregnant and non-pregnant animals was dependent on protein intake (Table 2), that of the pregnant animals was additionally dependent on the stage of gestation. The highest rate of protein deposition and the highest efficiency of protein utilization were recorded in mid-gestation. In addition, the protein deposition of the pregnant animals in both mid- and late gestation was greater than that of their non-pregnant litter sisters, with the largest difference on the low intake. Therefore pregnancy stimulated protein deposition, but the degree of stimulation appeared to be dependent on protein intake, being greater the lower the protein intake. A similar conclusion can be drawn from the results of Salmon-Legagneur (1965), Elsley et al. (1966), Rippel et al. (1968), Elliot \& Lodge (1978), De Wilde et al. (1974) and De Wilde (1980 a). The increase in total protein deposition during pregnancy was, however, entirely associated with accretion in the reproductive tissue and there was no evidence that the physiological state of pregnancy enhanced protein deposition in the maternal body since it was less than that of the non-pregnant control animals. This lack of pregnancy anabolism in the maternal body is compatible with the findings of Hovell et al. (1977a), Lodge et al. (1979) and De Wilde $(1980 a)$, but in contrast with those of Salmon-Legagneur (1965), Elsley et al. (1966) and Heap \& Lodge (1967). In the comparison and interpretation of results between pregnant and non-pregnant animals, it is important to distinguish between the short-term effects directly associated with pregnancy per se, that is in the reproductive tissue, and those 
long-term effects that persist in the maternal body. This distinction has not always been recognized and may be responsible for the differences in interpretation which have arisen from the various sets of experiments.

The changes of fat deposition were more extreme than those of protein deposition. On the low feed intake, body fat was used for both maternal maintenance and synthesis of reproductive tissue in late gestation. Thus anabolic and catabolic processes were occurring simultaneously at considerable rates. Although the site from which fat was mobilized was not known, results from experiments at comparable levels of feeding would suggest that a reduced lipogenic activity of the subcutaneous adipose tissue occurred during pregnancy (Etienne \& Henry, 1973) and a considerable reduction in backfat thickness during the first two parities (Whittemore et al. 1980).

The extent of maternal fat mobilization on the low level of feeding was greater than that indicated from total ER or total fat deposition. The estimate of fat loss of $140 \mathrm{~g} / \mathrm{d}$ at term refers to an animal maintained within thermal neutrality. If conditions vary then both the period at which mobilization occurs and its extent are changed. At an environmental temperature of $13^{\circ}$, that is, $5^{\circ}$ below the animal's critical temperature (Holmes \& Close, 1977), and on the basis that each $1^{\circ}$ decrease in temperature increases $M E_{\mathrm{m}}$ by $12 \mathrm{~kJ} / \mathrm{kg}$ body-weight ${ }^{0.75}$ per $d$ (Holmes \& McLean, 1974), it can be calculated that the animal would be in energy equilibrium at approximately day 70 of gestation and by day 110 would be losing some $240 \mathrm{~g}$ fat $/ \mathrm{d}$. This is equivalent to a loss of $4.8 \mathrm{~kg}$ throughout gestation and represents up to $20 \%$ of the animal's body fat reserves (Agricultural Research Council, 1981). This is before the inevitable loss which subsequently occurs during lactation. Since there appears to be a direct relation between reproductive efficiency and fat content of the body (Frisch, 1976), repeated and prolonged application of these treatments would result in severely emaciated sows with a high incidence of infertility. Such a condition, that is the 'thin sow syndrome', has been reported under practical conditions by MacLean (1968) and induced experimentally by Hovell \& MacPherson (1977).

\section{The efficiency of energy utilization}

It has generally been assumed that $\mathrm{ME}_{\mathrm{m}}$ increases during pregnancy as a result of the increased metabolic demands of the rapidly-growing reproductive tissue (Brody, 1938; Verstegen et al. 1971; Holmes \& McLean, 1974). Estimates of the $\mathrm{ME}_{\mathrm{m}}$ and $k$, determined from the regression equations relating $\mathrm{ER}$ to $\mathrm{ME}$ intake throughout pregnancy, showed that there was little difference in $k$ between pregnant and non-pregnant animals. However, the values of $k$ derived from the previously-mentioned equations are higher than those determined on younger growing animals kept under thermally neutral conditions (Agricultural Research Council, 1981). There is little information to show how the energy costs of protein and fat deposition during pregnancy compare with those of non-pregnant animals. Hovell et al. (1977 a) found that the energetic efficiency of tissue deposition was increased during pregnancy, and quoted values of $0.80-0.92$ for the energetic efficiency of fat deposition. Estimates of the energetic efficiency of tissue deposition have been obtained in the present experiment by relating ME intake to the rates of protein and fat deposition. The equations relating ME intake $\left(y ; \mathrm{kJ} / \mathrm{kg}\right.$ body-weight $\mathrm{t}^{0.75}$ per $\left.\mathrm{d}\right)$ to protein deposition $\left(x_{1} ; \mathrm{kJ} / \mathrm{kg}\right.$ body-weight ${ }^{0 \cdot 75}$ per $\left.\mathrm{d}\right)$ and fat deposition $\left(x_{2} ; \mathrm{kJ} / \mathrm{kg}\right.$ body-weight $\mathrm{t}^{\cdot 75}$ per $\left.\mathrm{d}\right)$ were:

$$
\begin{aligned}
\text { pregnant animals: } y=422(\operatorname{SE} 27)+1.45(\operatorname{SE} 0.67) x_{1}+1 \cdot 13(\operatorname{SE} 0.12) x_{2} & (r 0.84), \\
\text { control animals: } y=420(\operatorname{SE} 22)+2.05\left(\operatorname{SE~0.61)} x_{1}+1 \cdot 11\left(\operatorname{SE~0.41)} x_{2}\right.\right. & (r 0.84) .
\end{aligned}
$$

The reciprocals of the coefficients of $x_{1}$ and $x_{2}$ give estimates of the energetic efficiences of protein $\left(k_{p}\right)$ and fat $\left(k_{f}\right)$ deposition of 0.69 and 0.88 respectively for the pregnant animals. 
Table 3. Estimates of the maintenance energy requirements $\left(M E_{m} ; k J / k g\right.$ body-weight ${ }^{0 \cdot 75}$ per $d)$, the net efficiency of energy retention $(\mathrm{k})$ and the energetic efficiency of protein $\left(\mathrm{k}_{\mathrm{p}}\right)$ and fat $\left(\mathrm{k}_{\mathrm{f}}\right)$ deposition of sows under different experimental conditions

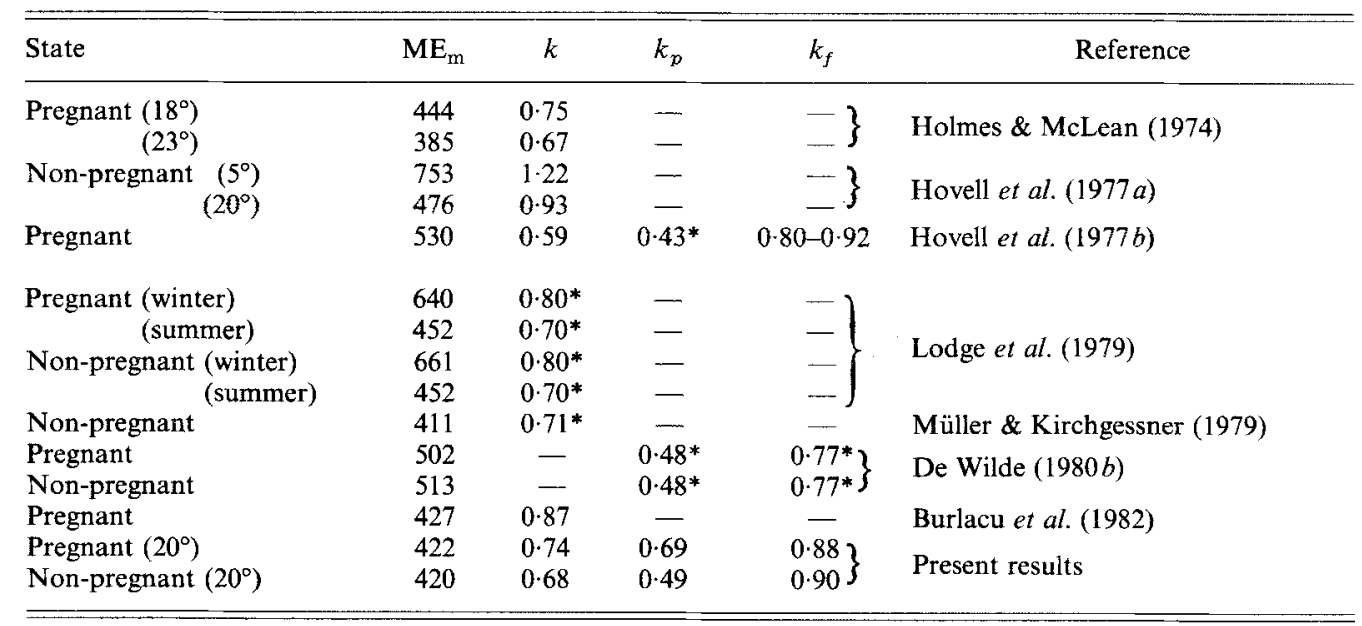

* Assumed values.

These compare with estimates of 0.49 and 0.90 respectively for the non-pregnant litter sisters. The corresponding values of $\mathrm{ME}_{\mathrm{m}}$ for the pregnant and control animals were 422 and $420 \mathrm{~kJ} / \mathrm{kg}$ body-weight ${ }^{0 \cdot 75}$ per $\mathrm{d}$ respectively.

There are few directly determined values of the energy costs of maintenance and production with which the present results may be compared. Most estimates of $\mathrm{ME}_{\mathrm{m}}$, for example, have been derived by assuming values of $k, k_{p}$ or $k_{f}$ (Table 3). However, the present results show that there is no difference in $\mathrm{ME}_{\mathrm{m}}$ or $k_{f}$ between pregnant and non-pregnant animals, with the later values being similar to those calculated on theoretical grounds (Agricultural Research Council, 1981). The higher $k_{p}$ value suggests an increased energetic efficiency of protein deposition during pregnancy.

Since the partition of total ER into its net maternal and reproductive components was known, it was possible to obtain separate estimates of the energetic efficiency with which these respective tissues were deposited. A multiple regression technique was used to partition $M E$ intake into components of maintenance, maternal gain $\left(E R_{M}\right)$ and reproductive gain $\left(E R_{R}\right)$. When calculated per $\mathrm{kg}$ body-weight ${ }^{0 \cdot 75}$ per $\mathrm{d}$, the equation was:

$$
\mathrm{ME}=424(\mathrm{SE} 37)+1 \cdot 15(\mathrm{SE} 0 \cdot 14) \mathrm{ER}_{\mathrm{M}}+1 \cdot 39(\mathrm{SE} 1 \cdot 01) \mathrm{ER}_{\mathbf{R}}
$$

The respective energetic efficiencies, that is $k_{\text {maternal }}$ and $k_{\text {pregnancy }}$, were 0.87 and 0.72 . The previous analysis assumes that the value of $\mathrm{ME}_{\mathrm{m}}$ is representative of the whole animal, that is both the maternal and reproductive tissue. It is similar to that calculated from both eqns (3) and (5). The value of 0.87 for the energetic efficiency of maternal tissue deposition is similar to that of mature animals depositing predominantly fat (Millward et al. 1976).

There are few direct estimates with which the present value of the energetic efficiency of pregnancy in the pig can be compared. For example, De Lange et al. (1980) determined a value of 0.21 within the last $7 \mathrm{~d}$ of pregnancy, based on the estimation of energy accretion in the uterus and mammary tissue by De Villiers et al. (1958). De Wilde (1980a) calculated a value of 0.33 throughout pregnancy but remarked on its uncertainty because of the rather unrealistic values obtained with certain animals. Schneider \& Bronsch (1977), on the other 
hand, calculated a value of 0.52 , that is, comparable with the present estimates. Their value was based on the values of Salmon-Legagneur (1965) for intra-uterine gain and estimates of $k_{p}$ and $k_{f}$ proposed by Thorbek (1975). Since between 60 and $70 \%$ of the energy in the reproductive tissue is retained as protein, it follows that the value of $k$ will be lower than that during growth or fattening. Since the values of protein and fat deposition at the different stages of gestation are known, and using the preferred estimates of $k_{p}$ and $k_{f}$ of 0.54 and 0.74 respectively (Agricultural Research Council, 1981), a mean $k_{\text {pregnancy }}$ value of 0.60 was calculated. This compares with the value of 0.72 from the present results and that of 0.80 used by the Agricultural Research Council (1980) to determine the energy requirements for intra-uterine deposition in the pig. In ruminants the Agricultural Research Council (1980) has proposed the value of 0.13 as the best estimate for the efficiency of $\mathrm{ME}$ for the maintenance and production of the ruminant conceptus.

Since the rate of energy deposition in the reproductive tissue is small relative to the total, large differences in the value of $k_{\text {pregnancy }}$ do not markedly influence the estimation of the total daily requirements of $\mathrm{ME}$. In relation to the total daily requirements of $\mathrm{ME}$, that required for the reproductive tissue increases from approximately $3 \%$ at day 50 to $15 \%$ at day 110 of gestation. Throughout gestation the energy retained in the reproductive tissue represents no more than $10 \%$ of the total. This is equivalent to a $3 \mathrm{~kg}$ increase in the weight of the maternal body of the sow.

\section{REFERENCES}

Agricultural Research Council (1980). The Nutrient Requirements of Ruminant Livestock. Slough: Commonwealth Agricultural Bureaux.

Agricultural Research Council (1981). The Nutritent Requirements of Pigs. Slough: Commonwealth Agricultural Bureaux.

Brody, S. (1938). University of Missouri, College of Agriculture, Agricultural Experimental Station Research Bulletin no. 283, 1-28.

Brouwer, E. (1965). European Association for Animal Production Publication no. 11, 441-443.

Burlacu, Gh., Iliescu, M. \& Caramida, P. (1982). European Association for Animal Production Publication no. $29,222-224$.

Close, W. H., Heavens, R. P., Noblet, J. \& Start, I. B. (1978). Journal of Physiology, London 284, 11-12P.

De Lange, P. G. B., Van Kempen, G. J. M., Klaver, J. \& Verstegen, M. W. A. (1980). Journal of Animal Science 50, 886-891.

De Villiers, V., Sørensen, P. H., Jacobsen, P. E. \& Moustgaard, J. (1958). Kungliga Veterinaer og Landbøhogskolens Institut fur Sterilitetsforskning, Arsberetning 137-145.

De Wilde, R. (1980a). Livestock Production Science 7, 497-504.

De Wilde, R. $(1980 \mathrm{~b})$. Livestock Production Science 7, 505-510.

De Wilde, R., Van Spaendonck, R. \& Vanschoubroek, F. C. (1974). European Association for Animal Production Publication no. 14, 197-200.

Elliot, J. I. \& Lodge, G. A. (1978). Canadian Journal of Animal Science 58, 43-48.

Elsley, F. W. H., Anderson, D. M., McDonald, I., MacPherson, R. M. \& Smart, R. (1966). Animal Production 8, 391-400.

Etienne, M. \& Henry, Y. (1973). Annales de Zootechnie 22, 311-316.

Frisch, R. E. (1976). In Meat Animals, Growth and Productivity, pp. 327-341 [D. Lister, D. N. Rhodes, V. R. Fowler and M. F. Fuller, editors]. New York and London: Plenum Press.

Heap, F. C. \& Lodge, G. A. (1967). Animal Production 9, 237-246.

Holmes, C. W. \& Close, W. H. (1977). In Nutrition and the Climatic Environment, pp. 51-73 [W. Haresign, H. Swan and D. Lewis, editors]. London: Butterworths.

Holmes, C. W. \& MacLean, N. R. (1974). Animal Production 19, 1-12.

Hovell, F. D. DeB., Gordon, J. G. \& MacPherson, R. M. (1977a). Journal of Agricultural Science, Cambridge 89, 523-533.

Hovell, F. D. DeB \& MacPherson, R. M. (1977). Journal of Agricultural Science, Cambridge 89, 513-522.

Hovell, F. D. DeB., MacPherson, R. M., Crofts, R. M. J. \& Pennie, K. (1977b). Animal Production 25, 281-290.

Kleiber, M. (1961). The Fire of Life. New York: Wiley \& Sons Inc.

Leitch, I. (1957). Proceedings of the Nutrition Society 16, 38-45.

Lodge, G. A. (1972). In Pig Production, pp. $399-416$ [D. J. A. Cole, editor]. London: Butterworths.

Lodge, G. A., Friend, D. W. \& Wolynetz, M. S. (1979). Canadian Journal of Animal Science 59, 51-61. 
MacLean, C. W. (1968). Veterinary Record 83, 308-316.

Millward, D. J., Garlick, P. J. \& Reeds, P. J. (1976). Proceedings of the Nutrition Society 35, 339-350.

Müller, H. L. \& Kirchgessner, M. (1979). Zeitschrift für Tierphysiologie, Tierernährung und Futtermittelkunde 42 , 271-276.

Noblet, J., Close, W. H., Heavens, R. P. \& Brown, D. (1985). British Journal of Nutrition 53, $251-265$.

Rippel, R. H., Rasmussen, O. G., Jensen, A. H., Norton, H. W. \& Becker, D. E. (1968). Journal of Animal Science 24, 203-208.

Robertson, E. C. (1969). Journal of Reproduction and Fertility 9, Suppl, 27-36.

Robinson, J. J., McDonald, I., McHattie, I. \& Pennie, K. (1978). Journal of Agricultural Science, Cambridge 91 , 291-304.

Salmon-Legagneur, E. (1965). Annales de Zootechnie 14, 1-135.

Salmon-Legagneur, E. \& Rerat, A. (1962). In Nutrition of Pigs and Poultry, pp. 206-233 [J. T. Morgan and D. Lewis, editors]. London: Butterworths.

Schneider, D. \& Bronsch, K. (1977). Zeitschrift für Tierphysiologie, Tierernährung und Futtermittlekunde 38, 43-51.

Shields, R. G. \& Mahan, D. C. (1983). Journal of Animal Science 57, 594-603.

Thorbek, G. (1975). Beretning fra Statens Husdyrbrugs Forsog no. 424.

Verstegen, M. W. A., Close, W. H., Start, I. B. \& Mount, L. E. (1973). British Journal of Nutrition 30, 21-35.

Verstegen, M. W. A., Van Es, A. J. H. \& Nijkamp, H. J. (1971). Animal Production 13, 677-684.

Whittemore, C. T., Franklin, M. K. \& Pearce, B. S. (1980). Animal Production 31, 183-190. 